\title{
The Legal System Application Affect Factors in Preventing HIV / AIDS Transmission in Bali
}

\author{
Prima Maharani Putri ${ }^{1 凶}$, I Gusti Ayu Ketut Rachmi Handayani², Hartono³, Widodo Tresno \\ Novianto $^{4}$ \\ 1 Fakultas Kedokteran, Universitas Muhammadiyah Purwokerto, Indonesia \\ 1,2,3 Fakultas Hukum, Universitas Sebelas Maret, Indonesia \\ E-mail Korespondensi: primamaharaniputri@ump.ac.id
}

\begin{abstract}
The issue of HIV/AIDS as a human rights issue in relation to public health has in principle become a topic of conversation in international public health law. In 1946, the World Health Organization (WHO) proclaimed that the highest success of a goal of public health standards was success in the treatment of HIV/AIDS as a fundamental issue of human rights. According to the last data of November 2019, Bali was ranked in the top five cases of HIV/AIDS with the number of PEOPLE with HIV/AIDS reaching 22,034 people. Of the number of cases nationally, Bali ranks number five after DKI Jakarta and West Java, even if reviewed from the average percentage compared to the population, Bali ranks in the top two nationally after Papua. The data when compared to the previous two years data is very different, where in 2017, Bali is still ranked sixth nationally. This article reviews Factors that affect the application of the legal system in preventing the transmission of HIV / AIDS in Bali Province. This research is a normative juridical research. Designed using the statute approach and conceptual approach. The results showed that Factors that affect the application of the legal system in preventing the transmission of HIV / AIDS in Bali Province are Multi-interpretation due to conflict norms in various cases about HIV/AIDS in Indonesia.. However, it needs Immediately formulate improvements or spelled out in the Regulation of the Governor of Bali to be more synergistic fundamentally in terms of HIV/AIDS Prevention, especially its transmission management and elimination namely to The Regional Regulation of Bali Province No. 6 of 2014 on Child Protection; Local Regulation of Bali Province No. 4/2019 on Indigenous Villages and Local Regulations of Bali Province No. 3/2006 on HIV/AIDS Prevention, as well as adjusting the Laws and Regulations on it..
\end{abstract}

Keywords: HIV/AIDS, Legal System Application, Bali

\section{Abstrak}

Isu HIV / AIDS sebagai isu HAM dalam kaitannya dengan kesehatan masyarakat pada prinsipnya telah menjadi topik perbincangan dalam hukum kesehatan masyarakat internasional. Pada tahun 1946, Organisasi Kesehatan Dunia (WHO) menyatakan bahwa keberhasilan tertinggi dari tujuan standar kesehatan masyarakat adalah keberhasilan pengobatan HIV / AIDS sebagai masalah mendasar hak asasi manusia. Berdasarkan data terakhir November 2019, Bali menduduki peringkat lima besar kasus HIV / AIDS dengan jumlah PENYAKIT HIV / AIDS mencapai 22.034 orang. Dari jumlah kasus secara nasional, Bali menempati urutan kelima setelah DKI Jakarta dan Jawa Barat, bahkan jika ditinjau dari rata-rata persentase dibandingkan jumlah penduduk, Bali menempati urutan dua teratas secara nasional setelah Papua. Data tersebut jika dibandingkan dengan data dua tahun sebelumnya sangat berbeda, dimana pada tahun 2017 ini Bali masih menduduki peringkat keenam secara nasional. Artikel ini mengulas faktor-faktor yang mempengaruhi penerapan sistem hukum dalam pencegahan penularan HIV / AIDS di Provinsi Bali. Penelitian ini merupakan penelitian yuridis normatif. Didesain dengan menggunakan statute approach dan conceptual approach. Hasil penelitian menunjukkan bahwa Faktor-faktor yang mempengaruhi penerapan sistem hukum dalam pencegahan penularan HIV / AIDS di Provinsi Bali adalah Multi tafsir akibat konflik norma dalam berbagai kasus tentang HIV / AIDS di Indonesia. Namun perlu segera dirumuskan perbaikan. atau dijabarkan dalam Peraturan Gubernur Bali agar lebih sinergis secara fundamental dalam hal Pencegahan HIV / AIDS, khususnya pengelolaan dan pemberantasan penularannya yaitu dengan Peraturan Daerah Provinsi Bali Nomor 6 Tahun 2014 tentang Perlindungan Anak; Peraturan Daerah Provinsi Bali Nomor 4/2019 tentang Desa Adat dan Peraturan Daerah Provinsi Bali Nomor 3 Tahun 2006 tentang Pencegahan HIV / AIDS, serta menyesuaikan Peraturan Perundang-undangan di atasnya.

Kata Kunci: HIV / AIDS, Penerapan Sistem Hukum, Bali 


\section{Introduction}

An adagium According to Satjipto Rahardjo that reading the law is interpreting the law "The interpretation of the law is at the heart of the law, it is almost impossible for the law to be executed without opening the "door of interpretation". The interpretation of the law is an activity that is absolutely open to do, since the law is written". Achmad Ali considers that what is meant as law is manifested in the form of: 1) Law as a rule (law as sollen); 2) Law as reality (law as sein). ${ }^{2}$

That the law as a reality is the most important thing but does not mean that the law as a rule can be ignored, because the law as reality remains sourced from the law as a rule. It is only more concrete the law as a rule not only that is included in the mere positive law, but the overall social rules recognized by the highest authorities in society. Furthermore, Achmad Ali suggested that the law is: "A set of rules or rules set out in a system that determines what can be done and what no human being should do as a citizen in his or her community, which is sourced both from his own community and from other sources, which is recognized by the highest authorities in that society, and actually enforced by the citizens (as a whole) in his life, and if the rules are violated will give authority to the highest authority to impose sanctions of an external nature."

Of course, both law in action and law in the form of rules as contained in the law in book, the ideal side that is to be achieved as the highest achievement as the law aspired (ius conctituendum) is certainly the purpose of the law to achieve justice. Justice cannot be the sole purpose of the law. Because however the value of justice is always subjective and abstract, so justice together with certainty and efficacy is made a priority legal objective, according to the case in concreto.

HIV transmission management is the foundation to reduce the increase in the number of HIV/AIDS cases, because not everyone with HIV positive will become AIDS / enter the AIDS stage if properly elimination, because on the other hand, the development of HIV/AIDS has raised many new problems such asprejudice, rejection (ignorance), and discriminatory attitudes. Discrimination against people with HIV/AIDS is sometimes expressed as a social disease that will emerge next. ${ }^{3}$

Considering that Bali is an international tourist destination area which is very vulnerable to HIV / AIDS transmission, based on the results of research on HIV / AIDS that has been carried out, it shows that there are several factors that have led to the failure of a legal system based on procedural justice from the various existing laws and regulations. in stemming the spread of HIV / AIDS in Bali Province, especially on several variables including discrimination, stigma, understanding of transmission and protection for the community against HIV / AIDS. As a world tourist destination, it is inevitable that transmission patterns through sexual relations and drug trafficking are inevitable.

The issue of HIV / AIDS as a human rights issue in relation to public health in principle has become a topic of discussion in international public health law. In 1946, the World Health Organization (WHO) has proclaimed that the highest success of achieving the goal of public health standards is success in dealing with HIV / AIDS as a fundamental problem of human rights. ${ }^{45}$

CST Kansil, et.al, Pengantar Ilmu Hukum Indonesia, Rineka Cipta, Jakarta, 2014

Achmad Ali. 2002. Menguak Tabir Hukum. Jakarta: Toko Gunung Agung.

Hon. Justice Michael Kirby AC CMG, "Courts and Judges in the Era of HIV/AIDS (adapted and updated from earlier version published in DC Jayasuriya", HIV Law, Ethics and Human Reghts, (New Delhi: UNDP, 1995

4 Putri Prima Maharani., et al. Legal Protection for HIV/AIDS Patients in Indonesian Medical Services. International Journal of Advanced Science and Technology 28, no 20 (December 31, 2019): 534-539.

5 Mary Ann Torres, Public Health And International Law: The Human Right to Health, National Courts, and Access to HIV/AIDS Treatment: A Case Study from Venezula", Chicago Journal if International Law, (Chicago: Spring, 2002) 
Kosmik Hukum Vol. 21 No. 1 (2021): 10-17

E-ISSN: 2655-9242 | P-ISSN: 1411-9781

DOI: $10.30595 /$ kosmikhukum.v21i1.9704

Grafic 1 : Tabulation of HIV/AIDS in Indonesia by year

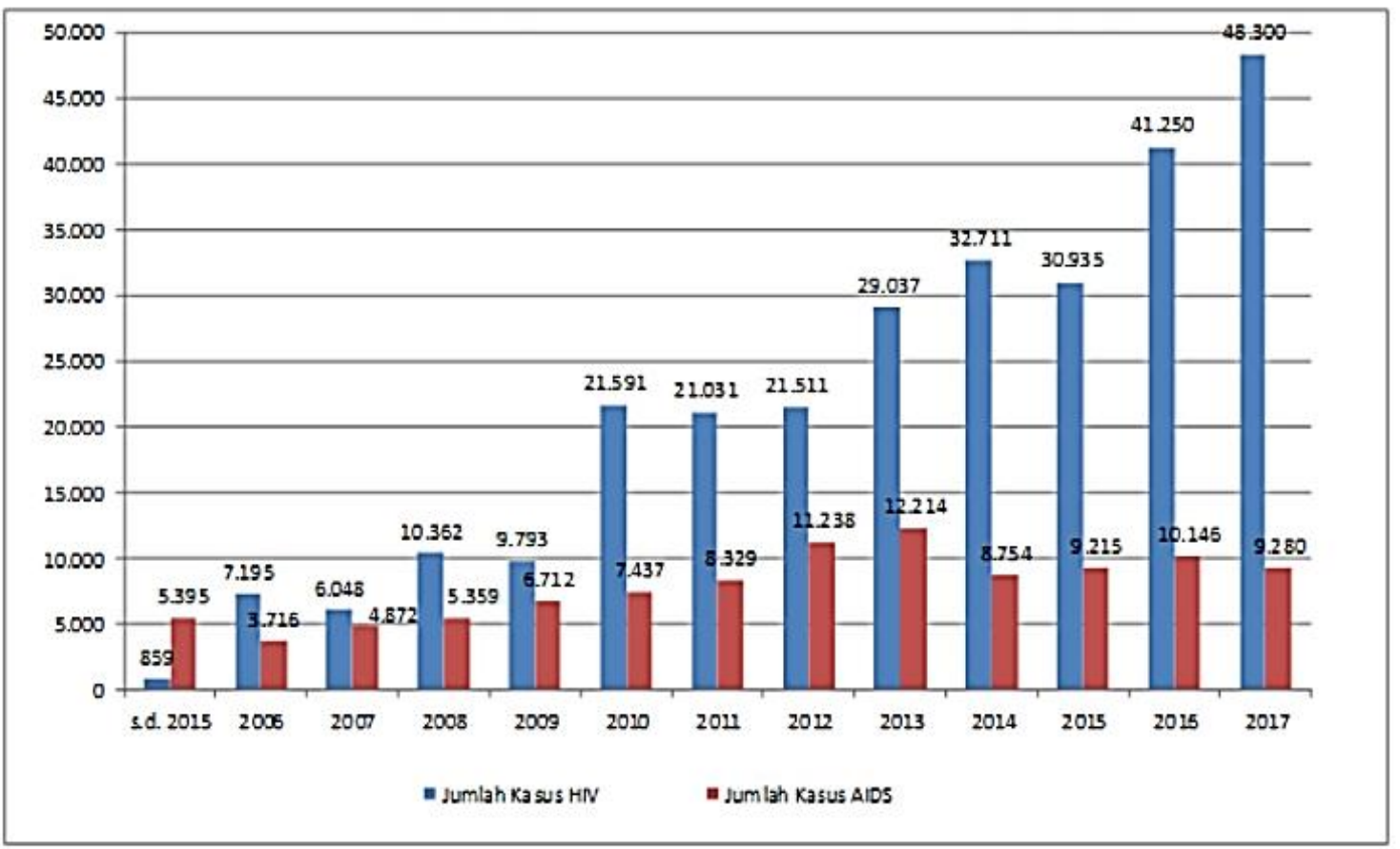

Source : Directorate General of P2P (HIV/AIDS and STI System 2018)

In addition, from some research that has been done, it can be seen the powerlessness of various regulations made by the government both ranging from the Law to the Ministerial Regulation and Local Regulations, for example:

1. The research conducted by Lidya Mellisa Bukit entitled "Cultural Dimension and Spread of HIV/AIDS disease in the people's love society" states that there are cultures and habits of karo people that influence their sexual behavior.

2. Zeth's research (2010) stated that soy behavioral factors such as free sex behavior, declining religious values and negative habits in Biak have a risk of contracting HIV/AIDS. The variables of moderators are the economy / jobs, lifestyle and households that have an influence on the risk of contracting HIV/AIDS disease.

3. Lestari Research (2013) entitled HIV/ AIDS Control Policy in Denpasar stated that the highest HIV/AIDS rate due to sex and the role of the government has not been optimal in its control.

4. Sri Handayani's 2016 research entitled Analysis of the implementation of HIV/ AIDS Prevention Program in Padang city looks still the absence of tupoksi and clear integration of each member of the KPA in the prevention of HIV / AIDS.

All parties do not yet understand that the treatment of HIV / AIDS is actually part of human rights that is in the fulfillment of the Right to health. Care and treatment are part of the right to the health of people with HIV that must be fulfilled (fulfil) by the state. Everyone's right to health is guaranteed in the Constitution of Indonesia, namely in Article 28H paragraph (1). In Health Law No. 36 of 2009 on Health (Health Law) it is stated that everyone: 6

1. Have equal rights in gaining access to health resources;

2. Have equal rights in obtaining safe, quality and affordable health care;

3. Entitled independently and responsibly to determine the health care necessary for him.

The guarantee of such rights implicitly says that not a single person, due to skin color, race, type of disease or any other reason, is excluded from the right to health. The rule is usually misinterpreted as the right to be healthy. The right to health is not the same as the right to be

6 Putri, Prima \& Murdi, Patria. (2019). Pelayanan Kesehatan di Era Jaminan Kesehatan Nasional sebagai Program Badan Penyelenggara Jaminan Sosial Kesehatan. Jurnal Wacana Hukum. 25. 80. 10.33061/1.jwh.2019.25.1.3046. 
healthy because the right to health consists of 2 (two) aspects namely freedom or freedom and entitlements or entitlements. ${ }^{7}$

Bali is a region that has strong customs and traditions, so in the implementation of stemming the transmission of HIV/AIDS which is the in fact the right azasi that must have a fundamental rule that is able to touch the roots of social life in society, in all elements, so it has been passed District Regulation No. 4 year 2019 regarding Indigenous Villages in Bali but does not refer to Law No. 6 year 2014 regarding Villages, but instead refers to Law No. 23 year 2014 regarding Local Government, Article 236 paragraph (4), which states that Perda may contain local content material in accordance with the provisions of the legislation. The basis of consideration is that through this perda also for the first time the Adat Village is officially recognized and explicitly as a legal subject with a clear and firm legal position regarding the reality of Adat Village as a natural cosmological unit of Bali that is socio-religiously tied to a balinese natural cosmologist called kahyangan jagat.. Between balinese people and customary law shows a connection. From the relationship it can be said that it is the people who embody the customary law and the community becomes the place / place of the validity of customary law, and in the community also the customary law is born, lived, grown and developed. The existence of customary law in society is basically to meet the living needs of the community itself, namely the need for peace of living together. This means that by applying the patterns of customary law in life together will create peace of life together. Customary law is a guideline for Balinese people, in terms of how to behave or act, so customary law regulates the behavior of citizens in the association of life. With such a function logically there is a consequence that there is a measure to see which behavior patterns are appropriate and which patterns of behavior are not appropriate. Against inappropriate behavior will be held corrections, corrections and sanctions carried out according to the size of customary law. ${ }^{8}$

Providing space and accommodating Perda No.4 year 2019 regarding Adat Village into an elaboration to responsive legal theory brings a fresh wind to the management of HIV/AIDS transmission in Bali, because the orientation of the legal system in the prevention of HIV/AIDS in Bali that has been there tends to be stuck in a sense of procedural fairness only on positivity but produces legal products that have low effectiveness for balinese people, so the presence of this theory provides a lot of new hope for the orientation of a legal system that is more responsive to the order of values and customs that live in the social order of balinese people.

Responsive legal theory holds that "a good law should provide something more than just a legal procedure. The law must be competent and also fair so that it should be able to recognize the wishes of the public and have a commitment to the achievement of substantive justice." ${ }^{9}$

Social change and social justice in tackling HIV/AIDS require a responsive legal order. This need has actually become the main theme of all experts who agree with the functional spirit, pragmatic, and purposive spirit (goal-oriented), as has Roscoe pound, adherents of legal realism, and contemporary critics so that The model of rules,can no longerreliably handle the dynamics of social needs amid the endless changes of today 10

If we review the prevailing legal system in Hospital Services, in Article 29 paragraph (1) letter b of Law No. 44 year 2009 regarding Hospitals ("UURS") it is mentioned that every Hospital has an obligation among others to provide safe, quality, anti-discrimination, and effective health services by prioritizing the interests of patients in accordance with hospital service standards. If the hospital violates these obligations, then under Article 29 paragraph [2] the hospital law in question will be subject to administrative sanctions in the form of:
a. reprimand;
b. written reprimand; Or
c. fines and revocation of hospital permits.

\footnotetext{
Komite Hak Ekonomi, Sosial, dan Budaya, Komentar Umum Nomor 14: Hak Atas Standar Kesehatan Tertinggi yang dapat dcapai, E/C.12/2000/4, 11 Agustus 2000

8 St. Laksanto Utomo, Hukum Adat, (Jakarta, PT Raja Grafindo Persada, 2016)

9 Bernard L. Tanya, et.al.Legal Theory, Cross-Space and Generational Human Order Strategy. (Yogyakarta: Genta Publishing, 2010)

10 National Standard of Hospital Accreditation Issue 1, 2017
} 
Kosmik Hukum Vol. 21 No. 1 (2021): 10-17

E-ISSN: 2655-9242 | P-ISSN: 1411-9781

DOI: 10.30595/kosmikhukum.v21i1.9704

Every hospital patient (including for ODHA patients) is given the right by law to obtain humane, fair, honest, and non-discriminatory services. It is also stipulated in Article 32 letter c uurs jo. Article 4 letter g law No. 8 year 1999 regarding Consumer Protection - "UUPK". But it does not explicitly mention in its own article on services for HIV/AIDS. The content on HIV / AIDS is only contained in the National Standard of Hospital Accreditation, which is mentioned that the Hospital carries out HIV/AIDS prevention in accordance with the laws and regulations and in accordance with the service standards for the referral of people with HIV/AIDS (ODHA) and its satellites with the following implementation measures: 11

1. improving the functioning of Voluntary Counseling and Testing (VCT) services;

2. improving the service function of Prevention Mother to Child Transmision (PMTCT);

3. improving the function of Antiretroviral Therapy (ART) services or in cooperation with designated hospitals;

4. improving the service function of Opportunistic Infections (IO);

5. improving service function in ODHA with Injection Drug Use (IDU) risk factors; and

6. improving the function of support services, which include: nutrition services, laboratories, and radiology, recording and reporting.

Being a fuzzy norm is what is meant in the phrase "... in accordance with the legislation", because in Law No.44 year 2009 regarding Hospitals is also not mentioned explicitly about HIV/AIDS services.

\section{Research Method}

The research method used in this study is a normative juridical, statutory approach and conceptual approach. The specification of this research is descriptive research. The data used in the form of secondary data with the main material in the form of primary legal material (legislation) and secondary legal material in the form of literature textbooks and scientific journals. The data obtained were analyzed using qualitative analysis.

\section{Result and Discussion}

Factors that affect the application of the legal system in preventing the transmission of HIV / AIDS in Bali Province

Namely in one of the clauses contained in the HIV/AIDS law in Indonesia, which is written as follows:

1. Anyone who is due for his or her job or for any reason knows and has information on a person's HIV status must keep it confidential.

2. Health workers or counsellors with ODHA approval as referred to in paragraph (1) may open information to their sexual partners in the case of:

a. ODHA who is unable to convey its status after receiving sufficient counseling;

b. there are indications there has been transmission in his sexual partners;

c. for the benefit of providing treatment, treatment and support to their sexual partners.

In other clauses written in the Criminal Code

1. Anyone who violates the provisions of the Article (which writes ....shall keep it confidential) is sentenced to a maximum imprisonment of 6 (six) months or a maximum fine of Rp. 50,000,000.00 (fifty million rupiah).

2. The crime as referred to in paragraph (1) is a violation

The clause stipulated in the clause contains conflicting norms against the above legislation, so that with this provision causes fear of health workers so that among health service workers and among the fasyankes in Bali Province there becomes no openness in the treatment of an HIVAIDS sufferer that will ultimately have a bad impact on the health care workers themselves, the

11 Eddy O.S. Hiariej, Theory and Law of Proof, Erlangga, Jakarta, 2012 
public in general, and even impact on the prevention of HIV-AIDS disease. The validity of norms is fundamental in a positive legal order, so juridical understanding begins with the interpretation of the object. This can lead to a dynamic interpretation of norms, appearing and disappearing according to the interpretation of a judicial decision or a legal product. The onset of "fuzzy norms" and "conflict norms" in existing health law policies "ostensibly" corroborates the legality of nullum delictum nulla poena sine praevia lege poenali meaning that there is no criminal act if there is no law or rule governing the prohibition of such acts, or azas nulla poena sine lege (no criminal offence stipulated under the Act). ${ }^{12}$

Legally, in the Perspective of Medical Disputes In Indonesia it is mentioned that this relates to medical information, is information about the condition in a file called medical records, which has the value of confidentiality. In a simple sense medical records are only records and documents containing about the condition of the patient's condition, but if further reviewed medical records have a complex meaning not only ordinary records, because in the record has been reflected all information concerning a patient that will be used as a basis in determining further actions in the service efforts and medical actions of Iainnya given to a patient who comes to the hospital. ${ }^{13}$

According to Decree No: 269/MENKES/PER/III/2008, Medical Records is a file containing records and documents about the patient's identity, examination, treatment, actions and other services that have been provided to the patient. Medical Records has a very good understanding of not only recording activities but having a definition as a system of organizing an installation / activity unit. While the recording activity itself is only one form of activity listed in the task description in the unit / installation of medical records. The process of conducting medical records begins at the time of receiving the patient in the hospital, followed by the activity of recording the patient's medical data by a doctor or dentist or other health professional who provides directly health services to the patient. As long as the patient gets medical services in the hospital, and continues with the management of medical records files that include the maintenance of storage and the expenditure of files from the storage to serve the request / borrowing because the patient comes to treatment, treatment, or for the purposes of lainnya. Medical records that already use computerized systems can produce data sourced in all health care activities in a health care institution. The processing of data and information about the patient's health condition can not only be stored in the medical records physically, but the data and medical information of a patient must also be stored automatically using a reliable computerized system so that the medical information of the patient's health condition is data and information that can be accounted for its validity and accuracy.

In discussions among the administrators of the Indonesian Hospital Association (PERSI) it is known that in granting access rights to medical records, the hospital must comply with the applicable law. Law No. 29 year 2004 regarding the practice of medicine already regulates that every doctor and dentist in conducting medical practice must make medical records and medical records must be kept confidential by doctors or dentists and the leadership of health care facilities.

Regulation of the Minister of Health no. 269 year 2008 regarding Medical Records states that although information about identity, diagnosis, disease history, examination history and medical history of patients must be kept confidential by clinicians, management officers and health facilities leaders, but this information can be opened among others to fulfill the request of law enforcement officials at the behest of the court and fulfill the request of institutions / institutions in accordance with the provisions of the legislation. The request must be submitted in writing to the hospital leadership.

In addition, this Decree also regulates ownership, benefits and responsibilities in managing Medical Records. Medical records are the property of the health service and its contents in the form of a summary of medical records are the property of the patient. Such summary may be

12 Dewa Ayu B. Handayani, Medical Dispute Perspective in Indonesia, Yuma Pustaka Surakarta, 2019

13 Titon Slamet Kurnia, Right to Optimal Health Degree as Human Rights in Indonesia, Alumni, Bandung, 2007 
Kosmik Hukum Vol. 21 No. 1 (2021): 10-17

E-ISSN: 2655-9242 | P-ISSN: 1411-9781

DOI: 10.30595/kosmikhukum.v21i1.9704

provided, recorded or copied by the patient or authorized person or with the written consent of the patient or his/her family who is entitled to it. Medical records can be used to:

1. Health Care and Patient Care,

2. Evidence Tools in the Law Enforcement Process,

3. Disciplines of Medicine and Dentistry and Ethics Enforcement of Medicine and Dentistry,

4. Education and Research Needs,

5. Basic Health Care Cost Payers, and Health Statistical Data.

Except for education and research conducted for the benefit of the state, the utilization of medical records that mention the identity of the patient must be approved by the patient and his heirs and must be kept confidential. Based on applicable regulations in Indonesia as described above, medical records cannot be opened to unlicised parties as they would be unlawful. This is different from in other countries, for example in America, where medical records documents can be accessed more easily by other parties, namely:

1. The patient himself, the patient's parents or the guardian responsible for looking after the patient can obtain a complete copy of the medical record (not a summary copy of the medical record as in Indonesia)

2. Family/close relatives or caregivers, but there needs to be written permission from the patient who owns the medical record

3. Providers have the right to view and share, forexample primary care physicians can share a patient's medical records with a specialist doctor where the patient is referred. These providers include laboratories, nursing homes, payers, technology providers and so on.

4. Health care payers (insurance companies, Medicare, Medical workers compensation, Social Security disability, Department of Veterans Affairs, including companies where patients work, if a portion of the cost of the service is borne by the company).

5. The government, not only the agency responsible for bear some or all of the cost of the patient's health care, but also other agencies, for example if the patient gets caught in a legal problem (as the perpetrator or victim).

6. Other parties in accordance with applicable regulations.

Thus, there is a legal disharmony between the obligation to hold confidential medical records related to information on hiv and AIDS status of a person with the basic need to obtain health information data as the basis for the preparation of HIV AIDS prevention policy. The right to health information for the public related to the transmission of harmful diseases is a right that must be fulfilled so that through that information the public can avoid the transmission of disease. This right is one of the basic rights of human rights, including the right to medical secrets of a person suspected of infectious diseases is a basic individual right that must also be respected. ${ }^{14}$ Legislation relating to people with HIV/AIDS becomes a guideline and legal basis for protecting and guaranteeing the rights of each individual 15

\section{Conclusion}

A legal system based on substantive justice for HIV/AIDS transmission in Bali Province can be achieved if it is established and implemented by making changes to the local government's perspective in order to List and use as one of the legal basis for Law No. 44 of 2009 on hospitals so that it becomes clear the system and the level of referrals and financing patterns. Regulation of the Minister of Health of the Republic of Indonesia No. 52/2017 about Elimination of Transmission of Human Immunodeficiency Viruses, Syphilis, and Hepatitis B from Mother to Child, Regulation of the Minister of Health of the Republic of Indonesia No. 87/2014 About

\footnotetext{
14 P. Maharani Putri, I.G.A.K. Rachmi Handayani, W. Tresno Novianto, Legal Protection for Children Affected HIV/AIDS in Indonesia, Proceedings of the $3^{\text {rd }}$ International on Globalization of Law and Local Wisdom (ICGLOW2019). Atlantis Press: 193-196.

15 Helena Nygren-Krug, 25 Questions and Answers on Health and Human Rights, (World Health Organization, 2002)
} 
Antiretroviral Treatment Guidelines, Immediately formulate improvements or spelled out in the Regulation of the Governor of Bali to be more synergistic fundamentally in terms of HIV/AIDS Prevention, especially its transmission management and elimination namely to The Regional Regulation of Bali Province No. 6 of 2014 on Child Protection; Local Regulation of Bali Province No. 4/2019 on Indigenous Villages and Local Regulations of Bali Province No. 3/2006 on HIV/AIDS Prevention, as well as adjusting the Laws and Regulations on it.

\section{References}

Ali, Achmad. 2002. Menguak Tabir Hukum. Jakarta: Toko Gunung Agung

Bernard L. Tanya, et.al.Legal Theory, Cross-Space and Generational Human Order Strategy. (Yogyakarta: Genta Publishing, 2010)

Dewa Ayu B. Handayani, Medical Dispute Perspective in Indonesia, Yuma Pustaka Surakarta, 2019

Eddy O.S. Hiariej, Theory and Law of Proof, Erlangga, Jakarta, 2012

Helena, Nygren-Krug, 25 Questions and Answers on Health and Human Rights, (World Health Organization, 2002)

Hon. Justice Michael Kirby AC CMG, "Courts and Judges in the Era of HIV/AIDS (adapted and updated from earlier version published in DC Jayasuriya", HIV Law, Ethics and Human Reghts, (New Delhi: UNDP, 1995)

Komite Hak Ekonomi, Sosial, dan Budaya, Komentar Umum Nomor 14: Hak Atas Standar Kesehatan Tertinggi yang dapat dcapai, E/C.12/2000/4, 11 Agustus 2000,

Mary Ann Torres, Public Health And International Law: The Human Right to Health, National Courts, and Access to HIV/AIDS Treatment: A Case Study from Venezula", Chicago Journal if International Law, (Chicago: Spring, 2002)

Putri, P. Maharani, I.G.A.K. Rachmi Handayani, W. Tresno Novianto, Legal Protection for Children Affected HIV/AIDS in Indonesia, Proceedings of the $3^{\text {rd }}$ International on Globalization of Law and Local Wisdom (ICGLOW2019). Atlantis Press: 193-196.

Putri, Prima \& Murdi, Patria. (2019). Pelayanan Kesehatan di Era Jaminan Kesehatan Nasional sebagai Program Badan Penyelenggara Jaminan Sosial Kesehatan. Jurnal Wacana Hukum. 25. 80. 10.33061/1.jwh.2019.25.1.3046.

Putri, Prima Maharani., et al. Legal Protection for HIV/AIDS Patients in Indonesian Medical Services. International Journal of Advanced Science and Technology 28, no 20 (December 31, 2019): 534539.

ST Kansil, et.al, 2014, Pengantar Ilmu Hukum Indonesia, Jakarta: Rineka Cipta

St. Laksanto Utomo, Hukum Adat, (Jakarta, PT Raja Grafindo Persada, 2016)

Titon Slamet Kurnia, Right to Optimal Health Degree as Human Rights in Indonesia, Alumni, Bandung, 2007 